\title{
'Responsibility to Prosecute' in an age of global governmentality: The International Criminal Court
}

Cooperation and Conflict 20I6, Vol. 5I(I) 20-37

(C) The Author(s) 2015

Reprints and permissions: sagepub.co.uk/journalsPermissions.nav DOI: $10.1177 / 0010836715597946$ cac.sagepub.com @SAGE

\section{Gozde Turan}

\begin{abstract}
This paper critically examines the discursive power of the International Criminal Court (ICC), which was established in 2002 with unprecedented jurisdiction in terms of both crimes being prosecuted and territorial scope. What evokes a critical engagement is not only the criminalization of certain acts in international law, but also the evolution of a permanent international criminal court with forms of power enabling the sanctioning, prosecution and punishment of these acts. Analysing how current international criminal law developed and is being shaped brings to the surface particular power structures embedded in legal texts and practices. By subjecting the discourse of the ICC to a Foucauldian analysis and arguing for the utility of Foucault's concepts in analysing contemporary international criminal legal discourse, the paper contributes to our understanding of novel techniques and procedures of contemporary global governmentality, and how the 'international community' is constituted as both a subject and an object within this recent power modality.
\end{abstract}

\section{Keywords}

Discursive power, global governmentality, international criminal court, international criminal prosecutions

\section{Introduction}

In the 20th century, a global human rights regime began to evolve, gaining significance through international institutions and covenants. ${ }^{1}$ Due to the dominant aim of discovering or establishing secure foundations, philosophical reflections on human rights have in time lost much of their critical nature and come to work primarily to confirm and reinforce the global human rights regime. ${ }^{2}$ While it might be argued that much criticism has

\section{Corresponding author:}

Gozde Turan, Department of International Relations, Faculty of Economics, Administrative and Social Sciences, Bilkent University, Bilkent, 06800 Ankara, Turkey.

Email: gozdeturan@bilkent.edu.tr 
been directed at human rights and violations thereof from within a legal discourse perspective, not much critical work has been done on this legal discourse itself. The main tendency to take human rights and humanitarian law as 'natural' categories and attribute a 'universal' feature to the legal discourse has led to what appears as the 'law-like necessity' of international criminal prosecutions, which has been administered by the International Criminal Court (ICC or 'the Court') since 2002.

In line with the recent literature seeking to fill the gap of critical insights in international criminal law (Cryer, 2005; Schwöbel, 2014), this article purports to question how the ICC acts as an agent of global governmentality and how its legal discourse shapes the mindsets of both its advocates and defiants. It is not a unique view that 'judicial power is an integral part and an important manifestation of the concrete social, political, and economic struggles that shape a given political system and cannot be understood in isolation from them' (Hirschl, 2009: 11). Still, the prevailing tendency regarding the self-imposed and voluntary judicial empowerment is to explain it in connection with the estimation of the power-holders that such a design would serve for their interests (Hirschl, 2009: 11), with the pragmatic search for effective, efficient and good governance (Elkin and Soltan, 1993; Slaughter, 2009), or with the increase of cross-border commercial activities and the rise of globalization (Benedict et al., 2005; Stone Sweet, 2006). This tendency does not only avert focus from initiatives to unsettle the dominant legal discourse, but also contributes to its maintenance and consolidation.

Drawing inspiration from the work of Michel Foucault, this article employs the concepts of discursive power and governmentality in an attempt to advance an alternative perspective on the Court's operation and the surge in support of international prosecutions, as well as to enrich the research agenda on international criminal law. 'Discourse', as a way of structuring areas of knowledge and social practice, is not just a set of spoken dialogue or written texts understood as mechanisms or processes preserved within a language. Rather, it is the very diversity of such mechanisms and processes that shows the relationship between discourse and knowledge that is complemented with reference to 'materiality' (Foucault, 1972: 112). Power, in its discursive form, is about how a specific set of rules organize and produce different forms of knowledge, and how different objects are (de)formed or (dis)appear (Foucault, 1972), and it is not confined to institutional or political arenas, but rather circulates through all spheres of life as a relational phenomenon (Foucault, 1980).

Whether taken as a developing subfield of international law or an interdisciplinary category borrowing from many disciplines (Armstrong et al., 2012: 193), international criminal law is a perfect reflection of discursive power floating within society while constructing particular subjects and identities, and shaping the very society it claims to act on behalf of. Being a subject matter of international criminal law, the ICC both shapes and implements the law that it embodies. In other words, it carries out a double mission by prosecuting what is defined as 'international crimes' and, simultaneously, developing the case law that is the primary guidance to understand the discourse of practices of the Court. The discursive practices of the ICC show how particular objects - that is, 'international crimes' or 'international peace and security' - are produced to speak of, deal with, analyse or explain. It is these practices that allow certain statements to justify and rationalize the acts of the ICC, the so-called international community and other actors in the broader context. 
Exploring different subjectivities that challenge or collaborate with the Court enables one to discern the power relations between actors and provides an opportunity to reread global justice mechanisms through the lens of governmental rationality. Rather than depending on overt violence, governmentality carries the idea of interdependency between governing subjects and manifestations of truth, which is no longer possessed exclusively by the state (Foucault, 2007: 357). Governmentality, in modern societies, operates through the power of truth at a distance, neither through compulsion nor in a direct manner (Miller and Rose, 2008: 42, 43). In this governmental rationality, 'the success or failure' of policies, rather than being confined to administrative agencies, is evaluated through 'techniques of notation, computation and calculation; procedures of examination and assessment; the invention of devices such as surveys and presentational forms such as tables; the standardization of systems of training and the inculcation of habits; the inauguration of professional specialisms and vocabularies' (Miller and Rose, 2008: 32, 39). For Foucault (1991: 102), governmentality refers to an 'ensemble formed by institutions, procedures, analyses and reflections, the calculations and tactics that allow the exercise of [a] very specific albeit complex form of power'.

A Foucauldian analysis of the ICC enables us to see, firstly, the global governance mechanisms as part of an aggregate global governmentality rather than a 'disaggregated world order' (Slaughter, 2009) and, secondly, an invasive rationality of international law's confinement of certain crimes and criminals as part of a recent punitive and governmental tactic. As a substitute of classical practices of exile, expelling or banishment, modern criminal law is inclined to confine the crime and the criminal (Foucault, 1977), which can be observed through the ICC at the global level. Considering communities, rather than individuals, in relation to a broader international community should not be taken as an indication of drawing boundaries between domestic and international politics, or an initiative to scale up the Foucauldian perspective with an aim to convert the theory to fit to the international. Hutchings (1997: 112) warns the Foucauldian scholar about the blurriness of boundaries between the domestic and the international domains, and underlines that the main interest would be more of relations of power floating through sub-state and trans-state levels. Rather than proposing a model for the international domain apart from the domestic politics, interpreting the ICC and international prosecutions through the concept of governmentality dwells on global governance mechanisms' inclination to observe, supervise and regulate communities partly due to concerns of feasibility and efficiency, mainly due to the change in perceptions on order, justice and security. It is this close relationship that has eroded the conventional demarcation lines in international affairs and changed perceptions on who stands at the centre and in the periphery. The ICC is a significant indicator that boundaries are drawn not in geographical terms, but in a different spatiality with reference to a consolidated relationship between global justice, order and security.

In order to grasp the ICC's discursive and governmental power operating both in and out of societies and state borders in a mutually constitutive fashion, the first part of the article will focus on potential outlets for applying Foucault's concept of governmentality to International Relations and International Law. The second part examines the discursive change making it possible for the ICC to be established in the first place. The shift in human rights and humanitarian law discourse in relation to a new security approach 
being the main outlet of the analysis, the aim is to clarify how discourses lead to different practices that construct particular objects. The focus of the third and final part is the outcomes and reflections of the particular discourse of the ICC through Foucault's governmentality concept. Foucault's understanding of novel techniques and procedures of governmentality contributes to a critical analysis of how the ICC discourse constructs different audiences and identities, and what sort of governmental rationality is in operation at the international level through governing mass-scale atrocities. It is the main argument of the article that the ICC discourse is part and parcel of current global security governance and it introduces a follow-up concept to 'responsibility to protect', namely 'responsibility to prosecute'. This concept stands in positive relation to a corresponding human security discourse that associates justice with security, and represents a crucial component of contemporary global governmentality.

\section{Foucault, international law and global governmentality}

The existence of contending approaches to Foucault's understanding of law makes it clear that there is no single way to interpret his legacy in the field of law and legal theory. In this connection, the conventional and commonly held conviction, which has been referred to as 'the expulsion thesis', is that Foucault treated law solely as a pre-modern way of imposing power by sovereign rulers or governments onto the subjects of the state, and that he consequently failed to take account of law being not merely repressive, but also constitutive (Fine, 1984; Hirst, 1986; Hunt and Wickham, 1994; Munro, 2001; Wickham, 2006). Against this, critics have argued that Foucault did not counterpose pre-modern law as an element of sovereign power and modern disciplinary power, but rather acknowledged that law and discipline coexisted and complemented each other (Beck, 1996; Ewald, 1991; Pavlich, 2001; Rose and Valverde, 1998; Tadros, 1998; Walby, 2007).

A more recent approach to Foucault's understanding of law seeks to re-evaluate the expulsion thesis and its critics in order not to refute them, but to connect them through a different perspective. Golder and Fitzpatrick (2009) stress that Foucault's law is both receptive and determinate. In being flexible, law is susceptible to domination whether it originates from a visible sovereign body or through more diffuse and invisible forms of disciplinary or bio-political power techniques. However, the argument that law can be dominated in such ways should not be confused with the expulsion thesis, which reduces law solely to an instrument of power. For Golder and Fitzpatrick, it is not despite but because of its susceptible nature that law cannot be contained by power (2009: 53-54). Furthermore, it is the heterogeneity of tactics, strategies, field of truths and rationalizations that enables one to observe and comprehend the various and uneven outlets of power constellations (Rosenow, 2009) as part of a system of 'governance without government' at the global as well as the domestic level (Rosenau and Czempiel, 1992).

Although it has become increasingly common to apply the concept of governmentality beyond the state level (Kiersey and Stokes, 2013; Larner and Walters, 2004; Neumann and Sending, 2010), some scholars have questioned the commensurability of carrying the concept to the international level. Selby (2007) argues that Foucault's main interest was techniques, modalities and rationalities of governance at the level of domestic societies within liberal western states, and these cannot be carried to the international due to 
the latter's specific ontological features. In his view, the international is still an arena of large actors wielding concentrated and centralized power. Like Selby, Joseph (2010, 2012) also has problems with the idea of making use of Foucault at the international level, as the overwhelmingly practised disciplinary power at this level supposedly contradicts with the domestic liberal governance techniques that do not equally permeate into all parts of the globe. The problem with these criticisms is that they overlook that governmentality operates alongside sovereign and disciplinary power, completing the triangulation of power modalities instead of following them in a sequential sense or precluding their concurrence (Foucault, 2007: 143). Besides the fact that governmentality comprises - at least in part - concentrated and centralized power mechanisms both at domestic and international levels, it is not only liberal governmentality that can be associated with liberal order. Thus, rather than recalling non-liberal orders besides liberal ones (Walters, 2012: 94-96), it would be more to the purpose to consider the contribution of sovereign and disciplinary power to liberal as well as non-liberal governmentalities.

Expanding liberal governmentality to comprise sovereign and disciplinary power modalities provides a better perspective on how power operates in different forms and fields, such as crime control (Carlson, 2014; Garland, 1997, 2002; Lea and Stenson, 2007; Merry, 2001; Mythen and Walklate, 2006; Stenson, 2005), in different regions that have so far been defined as marginal or irrelevant (Death, 2013; Guzik, 2013), and in international legal domains, such as investment law (Schneiderman, 2015), maritime law (Aalberts and Gammeltoft-Hansen, 2014), migration (Franke, 2011; Nah, 2012) or human trafficking (Legg, 2012). With regard to international law, looking at governmentality practices through a Foucauldian perspective reveals what is being made 'seen' through such law by means of different power modalities (Hammer, 2007; Orford, 2012) and also illustrates how micro techniques and strategies gradually permeate into global legal and political institutions, with the crucial novelty being that they are now applied by responsibilized subjects not limited to the state. However, instead of indicating a decline or weakening in state sovereignty, the intensifying interplay between states and international as well as supranational organizations represents a change in the construction of sovereignty and legal responsibilities that rely not on concepts or definitions with a determinate meaning, but rather on versatile techniques of governmentality (Aalberts, 2012a, 2012b; Aalberts and Werner, 2008, 2011; Rajkovic, 2012). Now more than ever, the state has turned into a means instead of an end in itself as one of the actors of global governmentality that 'brings together, arranges, and fixes within that arrangement the micro-relations of power' (Dean, 1994: 157). Being nothing but a temporal and historical form of stabilization of societal power relations, the state is just one of the governmentality techniques (Lemke, 2002: 58) that now hold novel responsibilities with regards to prosecuting international crimes in a complementary relationship with the ICC.

\section{The International Criminal Court: from 'responsibility to protect' to 'responsibility to prosecute'}

It is possible to trace both failed and successful initiatives to introduce limits on warfare back to antiquity, ancient Greece and ancient India (Cryer, 2005: 11-13). Against this long background of human rights and humanitarian law norms and rules, it is a very 
recent phenomenon that mass-scale atrocities are defined as international crimes and prosecuted at the international level. The Nuremberg and Tokyo Tribunals after the Second World War mark a real turning point in this respect, and are followed by the ad hoc tribunals for former Yugoslavia (ICTY) and Rwanda (ICTR), as well as the Special Court for Sierra Leone (SCSL). All these trials are regarded as significant steps paving the way for the establishment of the ICC, although none of them compares to the kind and scale of the latter.

\section{The ICC at a quick glance}

The Rome Statute establishing the ICC was adopted on 17 July 1998 and entered into force on 1 July 2002 after receiving the 60 required ratifications. As of May 2013, there are 122 state parties to the Statute. ${ }^{3}$ According to Article 5 of the Statute, the subject matter jurisdiction of the ICC is the crime of genocide, crimes against humanity, war crimes and the crime of aggression. Articles 13, 14 and 15 clarify the provisions enabling the Prosecutor of the Court to open an investigation regarding a situation upon referral by a state party, referral by the United Nations Security Council (UNSC) or upon his/her personal conviction. The Rome Statute enables investigation also of a non-state party if the UNSC decides that there exists a situation threatening international peace and security. In addition to the Prosecutor's right to commence with an investigation upon personal conviction, this possibility is a clear step beyond traditional international law, which takes 'sovereignty' and 'non-interference' in the domestic affairs of states as core principles. 4

To date, four state parties to the Rome Statute - Uganda, the Democratic Republic of the Congo, the Central African Republic and Mali - have referred situations occurring on their territories to the Court. In addition, the UNSC has referred the situation in Darfur, Sudan and Libya - both non-state parties to the Statute. Finally, there are two situations - Kenya and Cote d'Ivoire - that the Prosecutor initiated investigations upon being authorized by the ICC.

The ICC reflects the final stage in the codification of international criminal law, or a process of homogenization of criminal norms and rules at the international level. There are various ways to explain what made the establishment of the ICC possible, and many scholars have pointed to the end of the Cold War playing a key role (Horne, 2006; Scheffer, 2002; Struett, 2008). However, while the end of the Cold War certainly facilitated the ICC's establishment, the real motivation can be argued to have originated with a shift in the human rights discourse towards a focus on 'accountability' for mass-scale atrocities. Before this occurred, human rights were regarded as a body of norms and rules that mainly granted rights and freedoms, with the idea being that this, rather than the seemingly archaic practice of criminal justice based on punishment, would have the effect of preventing human rights violations. Against this background, the more recent emergence and institutionalization of international prosecutions signal that the earlier human rights discourse has been transformed into an accountability regime, within which an 'international community' is ascribed the responsibility not only 'to protect' the victims of what is codified as 'crimes', but also 'to prosecute' the perpetrators as 'criminals'. 


\section{International prosecutions as a recent practice}

While international criminal prosecutions are increasingly treated as part of the natural order of international things, there is nothing natural about a particular act being codified as a crime, nor about such an act being prosecuted. In this connection, Veyne (1997: 155) has argued

...[o]bjects seem to determine our behaviour, but our practice determines its own objects in the first place. Let us start, then, with that practice itself, so that the object which it applies is what it is only in relation to that practice ... The relation determines the object, and only what is determined exists.

Rather than being a universal or fixed reality, it is the practice of international criminal prosecution that has evolved over time and given rise first to the Nuremberg and Tokyo Tribunals, then to the ad hoc criminal tribunals for the former Yugoslavia and Rwanda and, finally, to the ICC. In order to understand this development, it is necessary to consider how the return to criminal justice through an accountability regime reflects a shift in perspective regarding what constitutes a threat to international security.

The main conviction framed through the human security concept in the post-Cold War era assumes that the real threat to human life derives not from inter-state but from civil and ethnic conflicts. The human security concept represents a different discourse on justice and security that eliminates traditional concerns of formal state boundaries, and points to the detrimental effect of problems external to warfare, such as hunger, disease or political disruptions threatening both individual and communal security (Martin and Owen, 2013). ${ }^{5}$ Instead of taking the state as the central focus of power, the recent human security discourse, which is now directly connected to human rights, takes it just as one of the actors to provide or to threaten justice, order and security; it is this changing discourse that has led to the establishment of the ICC as part of global security governance.

\section{Governing mass-scale atrocities}

Discourses have a transactional role rather than being merely functional for the governmental rationality, and introduce distinct means to govern individuals and communities to create and regulate subjectivities (Foucault, 1991). As power cannot penetrate into social and political strata when restricted to move on an unfounded and imperceptible ground, its operation is secured with these distinct means providing technicality and calculation that enable intervention through, firstly, problematization and, secondly, diagnosing, prescribing and solving the problem. The technical reflection and elaboration here is not confined to legal or economic domains; Foucault (2007: 353) points to the significance of a third category, 'security', which has become 'the fundamental objective of governmentality' especially after the 18th century. In this society of security, political security and social security have an interwoven relationship wherein the state undertakes to formulate the problems for the social (Gordon, 1991: 35). Problematization is a key component of governmentality, as who defines the problems also determines possible solutions, which is itself furthering the determination and delimitation on who can act and who has the legitimate or rational cause to act. 
'Government in the name of truth' finds its expression through a subsidiary mantra of 'government in the name of justice' in global security governance that juxtaposes, and at many points converges, security with justice. As long as it is not the mere consideration of territory or population as objects of neo-liberal governmentality, and rather a focus on the relations within the population through the things that do not only indicate wealth or resources, but also climate, irrigation, fertility; or manners, customs, ways of acting and thinking; or accidents and misfortunes such as famine, epidemics or death (Foucault, 2007: 96), global governmentality proceeds to deal with disasters through a 'mass-scale atrocities' discourse, talking on behalf of the 'international community', acting for the 'international community' and, in fact, 'managing' the parts supposedly constituting this community. The mission of putting diagnosis and finding solutions to the problem of international crimes is accomplished both by and for the international community through the expertise and technicality that is partially provided by international lawyers, jurists and legal experts, with the ICC representing the central locus. It is 'the international community [that] agreed on the creation of a permanent international court' (ICC Press Release, 2013a), and through this initiative, what has been established at Rome is not only a permanent international court because 'the world embarked upon an audacious plan to create a global justice system' (ICC Press Release, 2013a) or what may be called as an 'entire Rome Statute system' (ICC Press Release, 2013b) or simply 'the ICC system' (Song, 2013: 7) by signing the Rome Statute.

The Rome Statute represents a sort of contractual tutelage over both the state parties and non-state parties. The once-defined dichotomous relationship of the individuals or certain types of groups against the state is replaced by a scaled-up relationship between local communities and the international community, while it is impossible to suppose the latter to breach or pose any threat against individual or group rights. Population as the ultimate end of governmentality (Foucault, 2007: 105) finds its reflection for global governmentality through a focus on international community. Global governmentality embraces the concept of human security, which marks a break with more traditional security concepts through deepening as well as widening it from the level of the state to individuals and communities, and from military to non-military issues. The development of the human security concept introduces also a new global security governance model wherein state-centric bias transforms towards a complex network of state and non-state actors (Krahmann, 2003). In this complex network, mass atrocities are not just extreme incidents that would otherwise be symbols of pain and sorrow, and solely remain in rhetorical reflections.

There is clearly a relationship established between these atrocities that are codified as international crimes and international security, which means that governmental rationality at the international level moves with a consistent and steady emphasis on a certain type of security that is associated with the international community. The triangular relationship between the international community, mass atrocities as international crimes and security takes its expression in the Preamble of the Statute, where the state parties underline that 'during this century millions of children, women and men have been victims of unimaginable atrocities' and 'such grave crimes threaten the peace, security and well-being of the world' while 'the most serious crimes of concern to the international community as a whole must not go unpunished'. Atrocities constituting grave crimes 
with a great potential of threatening the peace, security and well-being of a wider community beyond traditional borders is a reiterated discourse in the decisions and judgements, as well as statements and press releases, of the Court.

Mass-scale atrocities cannot be left unnoticed even if there is a government-in-charge, and irrespective of the country being a state party to the Rome Statute or not. As the Darfur case shows, the existence of a functioning government does not preclude the ICC to intervene. What the Court recons is not the mere absence or presence of a ruling authority, but a particular type of relationship between the government and its citizens. What is at issue is not merely the protection of the basic right to life or the occurrence of mass-scale atrocities, but the lack of a properly functioning judicial system that meets the standards set forth by the international community. It is not just 'living', but 'better living' that becomes relevant for government intervention (Foucault, 2007: 338), and ensuring accountability for mass-scale atrocities is recognized as part of what constitutes 'better living'.

\section{Are there any puppeteers holding the strings of the ICC?}

Both mass-scale atrocities and incompetent or unwilling judicial systems are regarded as 'abnormal categories' in a similar fashion to the construction of the mentally ill as an incompetent subject and a perturber of society corresponding to an emergent public sensibility towards the socially irregular (Foucault, 1993). The international community's sensibility towards mass-scale atrocities is a similar construction in that the societies experiencing such atrocities and national jurisprudences not prosecuting such crimes properly are also perceived by the international community as irregular and incompetent. Governmentality envisages the interference and direct conduct of the central authority when the legally mandated private or local authority fails to perform as required. Until that happens, the rationale of governmentality is 'conducting the conduct at a distance', as it cannot meet all details of prosecutions in each case. Thus, the question is to understand this rationality rather than identifying 'the conductor(s)' in the grids of global governmentality.

The principle of complementarity, as clarified in Article 17 of the Rome Statute, fits well with the rationale of global governmentality, which operates horizontally rather than establishing hierarchical or sovereignty-based relations. The principle of complementarity reflects neither domination nor pure equal relations, but the 'power of partnerships' (Abrahamsen, 2004) in the legal field through constituting partners responsible to prosecute international crimes satisfying certain criteria of international law. The Court is authorized if and only when these criteria are not met and national courts appear to be unable or unwilling to prosecute the accused persons for the crimes enumerated in the Statute. In this way, the ICC contributes to the mapping and framing of the undeveloped, incompetent or simply the 'other'. The principle of complementarity, through ensuring the means for 'knowing the subject', involves a gradation of types of legal systems if not types of people. The ICC accomplishes a monitoring, surveillance and controlling process in which the performances of national legal systems vis-à-vis the atrocities are the key components of evaluation. In its report to the UN General Assembly (UNGA A/68/314, 2013: para. 40), the ICC indicates its negative assessment about the Libyan 
jurisprudence, stating that 'the Chamber concluded that Libya's national system was unable to secure the transfer of the accused into their custody or to carry out the proceedings in the case against Saif Al-Islam Gaddafi'. The same assessment is reiterated by the Prosecutor, 'Libya is unable genuinely to carry out the proceedings against Mr Gaddafi' (Bensouda, 2013: para. 15).

In fact, it is not only the ICC carrying out such an evaluation process. The UN bodies, instead of being dependent on reports from the ICC, may initiate their own evaluation process as is the case in the situation of Darfur, Sudan. The International Commission of Inquiry on Darfur established by the Secretary-General concluded:

...[t]he Sudanese justice system is unable and unwilling to address the situation in Darfur. The system has been significantly weakened during the last decade. Restrictive laws that grant broad powers to the executive have undermined the effectiveness of the judiciary, and many of the laws in force in the Sudan today contravene basic human rights standards. Sudanese criminal laws do not adequately proscribe war crimes and crimes against humanity, such as those carried out in Darfur, and the Criminal Procedure Code contains provisions that prevent the effective prosecution of those acts. (UN Security Council, 2005)

Producing technical and calculable knowledge is accomplished in collaboration with states as well as a wide array of domestic and global organizations which, in turn, provide these organizations with a suitable ground to deploy specific policies. It is pertinent to claim that states, as well as institutions and organizations, execute the duty that befalls them, while the ICC and the UNSC stand as the main stakeholders. The governmental rationality of neo-liberalism, which ascribes the individual citizen the role of both a player and a partner (Gordon, 1991: 36), finds its reflection in the global governmentality game through 'individual states' as members of the international community.

The problematization of certain acts as international crimes and the sort of technicality developed to deal with these crimes introduces in parallel a spurious de-politicization process. It is spurious, because defining law as an apolitical field is a means of preventing interventions from non-legal fields. Moreover, one of the main functions of the ICC is defined as 'encouraging domestic authorities to pursue accountability, pushing groups to renounce violence and embrace political solutions, and deterring leaders from the commission of grave atrocities' (ICC Press Release, 2013a), which obviously goes beyond a mere judiciary process. Undoubtedly, the initiatives and practices to encourage domestic authorities have a political character in their defining boundaries, constructing particular subjects, and leading to the mobilization of certain forces and entities both above and below the national level, all of which cannot be excluded from politics.

\section{Pseudo-resistance?}

Just as power has both a repressive and productive dimension enabling resistance and transgression, law also contains the potential of resistance and challenge due to its susceptible nature and the perpetual change and reconstruction that it gives rise to. In a similar way, the idea of justice is put to work either by rulers as an instrument of power, or by opponents as an instrument of resistance (Rabinow, 1984: 6). For what constitutes power is the freedom of its subjects who can act on a myriad of possibilities, and who can resist 
and challenge (Foucault, 2000); subjects are not passive or powerless instruments, even as their advocation or resistance do not represent constant foundations. Likewise, the discursive power of the ICC is challenged and resisted as well as advocated. The versatile and uncertain nature of relations between the subjects who change their positions against the ICC over time is a direct indicator not of the lack of any foundation or rationale embedded in the relations, but of the autonomy of the subjects, although this autonomy is framed by a particular discourse. The operation and discourse of the Court are not interpreted in the same way by subjects, as they are observed through the lenses of conflicting reactions from different groups. Rebels welcome the ICC arrest warrants of government leaders in Sudan against an on-going propaganda carried out by the Sudanese government declaring the Court as another attempt of the West to topple an Islamic regime. Uganda has dramatically changed its attitude from full-scale support for the ICC in its quest for international support against the rebel movement led by The Lord's Resistance Army (LRA) towards taking the lead in a continent-wide opposition against international prosecutions (Nouwen and Werner, 2010: 948-956). Examples of the politics of international criminal law not only illustrate the flexible and complicated nature of resistance, but also reveal another striking feature: 'If law eludes encapsulation by power, the same holds for resistance' (Krasmann, 2012: 390).

The ICC may well be contested within and beyond its regime, although the challenge seems to remain within the limits of the prevailing discourse that derives from the foundations of international human rights and humanitarian law evolving into a widely accepted and consolidating international criminal law discourse. Despite the increasing tension between the ICC and the African Union (AU), which intensified particularly following the warrant arrests issued for high-rank state officials in Sudan (including President al-Bashir), the Union calls for the African regional court (African Court of Human and People's Rights or AfCHPR) to investigate and prosecute suspects of international crimes as a counter-strategy against the ICC. ${ }^{6}$ As the chairman of the AU, Mutharika has declared he would not 'sweep the issue of al-Bashir under the table', but also underscored that 'Bashir could not and would not be tried outside the African soil' (Sudan Tribune, 2010). Musevini, the President of Uganda, depicts the ICC as an institution being misused by 'the pushers of the hegemonic agenda' (New Vision - Uganda's Daily Leading, 2014a), yet avoids criticizing the initially proclaimed aim of prosecuting international crimes. Kenyatta, the Kenyan head of state, who is the first sitting president to appear before the ICC, displays a different kind of resistance by not refusing to stand before the Court. So, the problem for the African countries and leaders seems to be the locus of the trial, the identity of the institution or its hidden intentions, not the discourse against impunity for international crimes.

Discourse, as a responsive and flexible structure of knowledge, formulates the appropriate template for both power and freedom. That is to say organizations as well as individuals are moving in a world moulded by discourses that are both granting and taking away freedom. In this connection, both Kenyan President Kenyatta, who challenges the Court by underlining that he 'cooperated with the prosecutor to assist in establishing the truth at all material times' (New Vision - Uganda's Daily Leading, 2014b), as well as national and international observers who accuse NATO and Coalition Forces of committing war crimes and crimes against humanity in Libya, are caught up in and constrained 
by a discursive 'truth' canvassing the current globe with elements of international crimes. Politicians or critical thinkers from various disciplines, in their challenge against the ICC, 'criticize instances of power' rather than the 'chief enemy', while the real struggle and resistance should be directed towards 'not so much such-or-such institution of power, or group, or elite, or class but, rather, a technique, a form of power' (Foucault, 2000: 330, 331). In this respect, defiant voices or acts against the ICC frustrate the potential for effective criticism as long as they apply rather than problematize and challenge the elements of the dominant discourse, and thereby fail to notice that power uses 'freedom to create constraints' (Koskenniemi, 2002: 177).

\section{Conclusion: from raison d'état towards raison d'internationale}

Incidents of mass-scale atrocities are no more taken merely as heinous or barbarous events taking place in remote parts of the world. Although the criminal tradition has turned its face towards individual responsibility of the crime committed, prosecution and punishment of the individual act has transformed into a collective initiative in connection with the modern mantra 'responsibility to protect'. So, the crime is individual, but prosecution is a collective responsibility reflecting the close relationship established between the international crimes and international peace and security. This is a relationship supporting and consolidating the 'responsibility to protect' and carrying it even to another level through what can be called the 'responsibility to prosecute'. On the other hand, the crimes codified as 'international crimes' have also a collective character, which contributes to mapping world communities according to a certain set of standards. The collective nature of international crimes and the reactions of the international community to these crimes represent a novel phase of governmentality at the international level. Just like so many different questions in economic, social, political or cultural fields, the problem of how to deal with particular atrocities has also been embedded in the matrices of liberal governmentality. The ICC, representing the final stage in international criminal prosecutions, operates both as an alienation and justification mechanism: alienation from temporal and spatial zones of conflict and justification for the means of achieving this alienation and governing not only the ones being categorized as 'others' but also the ones representing the so-called international community. Governing others turns into governing selves as past and present atrocities tell us a narrative urging the need and necessity of protecting the status quo.

The idea of justice that the ICC - in collaboration with numerous global governance bodies - promises to realize is an end in itself, which is supposedly in harmony with the well-being and happiness of everyone. Although lacking a materialized hierarchical state-organism at the international level, global governmentality introduces a parallel logic with that of the nation-state. The raison d'état of the nation-state has been described as the maintenance of the well-being and happiness of its citizens. However, the interest of the state in improving its citizens' well-being and happiness was not an ultimate end in this logic. Instead, this was an interest coinciding with that of the state itself. It was not because the well-being and happiness of citizens was a 'supreme and non-negotiable 
end', but because welfare of the citizens was a means to enable the state to survive and advance (Walters, 2012: 28). Global security governance also takes an interest in improving the welfare of its subjects, as well as prosecuting and punishing the ones threatening it. Here, again, there is an interaction between the well-being of the international community and the interests of global security governance. The ICC, as the final stage at international prosecutions, tries to protect and maintain 'justice', not because 'justice' is taken as a supreme and universal end, but because 'justice' is a means to an end, with the end being the survival and advancement of global governmentality.

Global governmentality's reference to freedom has been the fundamental principle to justify and rationalize liberal rationalities of rule. Now, this principle is supplemented with a follow-up reference to justice, although justice is understood in a particular manner in relation to human security. While the ICC discourse seems to be developing towards a human security-oriented one, the parameters of what constitutes human security remain highly limited and restricted. The type of security that should be established for the population does not go beyond actual physical survival, although a number of alternatives, such as preventing civilian unrest due to famine, providing a context for sustainable development or creating a viable program to eliminate illiteracy (Acharya, 2001), may well be integrated into this contemporary discourse. Although the state as the referent object of security has been replaced by human groups in this new discourse, what is understood by human security continues to imply and reproduce the old security understanding.

In addition, this new combination of justice, which has so far been interpreted through a rights-oriented discourse but is now incorporated into order and security concerns, results in a strange and even paradoxical relationship oscillating between granting and suppressing freedom. The security and order components in the recent discursive formation of the ICC contribute to a narrow and restrictive framework for international criminal law. Yet in another paradoxical way, the narrowly defined international criminal law discourse brings about a proliferation of new actors that do not function only to impose discursive power onto others, but also implement this discourse over the self. It is not the case that local authorities (i.e. states) delegate or renounce their power to an international or supra-national authority. Contrariwise, a globally functioning mechanism is ascribing certain duties and responsibilities to individual states, as well as organizations at various levels. Global governmentality moves within and beyond conventional borders governing the autonomous self in the form of states and many other actors.

In the case that the right to life disappears and populations become subject to massscale atrocities, these actors sharing the once sovereign power of the state intervene. Although the ICC is but one of these actors, it is a very crucial one indeed, and its discourse is perhaps the most conspicuous example of how changing threat and security perceptions lead to the construction of different identities, while conferring certain responsibilities to particular members of the so-called international community.

\section{Funding}

This research received no specific grant from any funding agency in the public, commercial or not-for-profit sectors. 


\section{Notes}

1. For a discussion on the global human rights regime, see Donnelly (2013: 161-192).

2. Although there are critiques of the unproductive nature of the philosophy of rights discourse (e.g. Evans, 2003, 2005; Manokha, 2009; Raphael, 1966; Vincent, 1986), these critiques do not cover the field of criminal law even if they consider the discursive power dimension of the problem.

3. For the full list of states parties to the Rome Statute, see http://www.icc-cpi.int/en_menus/asp/ states $\% 20$ parties/Pages/the $\% 20$ states $\% 20$ parties $\% 20$ to $\% 20$ the $\% 20$ rome $\% 20$ statute.aspx.

4. On the establishment as well as the organizational structure and procedures of the ICC, see Schabas (2011), Schiff (2008) and Stahn and Sluiter (2009).

5. The Human Development Report (UNDP, 1994) is the primary formal document signifying an important change in the security discourse.

6. For an elaborate analysis on the process initiated by the AU towards the establishment of the AfCHPR, see Abass (2013).

\section{References}

Aalberts TE (2012a) Constructing Sovereignty between Politics and Law. London: Routledge.

Aalberts TE (2012b) Patterns of global governmentality and sovereignty. In: Guzzini S and Neumann IB (eds) The Diffusion of Power in Global Governance: International Political Economy Meets Foucault. Houndmills: Palgrave Macmillan, pp. 229-255.

Aalberts TE and Gammeltoft-Hansen T (2014) Sovereignty at sea: the law and politics of saving lives in mare liberum. Journal of International Relations and Development 17(4): 439-468.

Aalberts TE and Werner WG (2008) Sovereignty beyond borders: Sovereignty, self-defense and the disciplining of states. In: Adler-Nissen R and Gammeltoft-Hansen T (eds) Sovereignty Games: Instrumentalising State Sovereignty in Europe and beyond. Houndmills: Palgrave Macmillan, pp. 129-150.

Aalberts TE and Werner WG (2011) Mobilising uncertainty and the making of responsible sovereigns. Review of International Studies 37(5): 2183-2200.

Abass A (2013) Prosecuting international crimes in Africa: Rationale, prospects and challenges. European Journal of International Law 24(3): 933-946.

Abrahamsen R (2004) The power of partnerships in global governance. Third World Quarterly 25(8): 1453-1467.

Acharya A (2001) Human security: East versus west. International Journal 56(3): 442-460.

Armstrong D, Farrell T and Lambert H (2012) International Law and International Relations. Cambridge: Cambridge University Press.

Beck A (1996) Foucault and law: The collapse of law's empire. Oxford Journal of Legal Studies 16(3): 489-502.

Benedict K, Krisch N and Steward RB (2005) The emergence of global administrative law. Law and Contemporary Problems 68(3-4): 15-62.

Bensouda F (2013) Sixth Report of the Prosecutor of the International Criminal Court to the UN Security Council pursuant to the UNSCR 1970 (2011). Available at: http://www. icc-cpi.int/en_menus/icc/structure $\% 20$ of $\% 20$ the $\% 20$ court/office $\% 20$ of $\% 20$ the $\% 20$ prosecutor/reports\%20and\%20statements/statement/Documents/Report $\% 20$ to $\% 20$ UNSC $\% 20$ Nov2013EN.pdf (accessed 3 August 2015).

Carlson JD (2014) States, subjects and sovereign power: Lessons from global gun cultures. Theoretical Criminology 18(3): 335-353. 
Cryer R (2005) Prosecuting International Crimes, Selectivity and the International Criminal Law Regime. New York: Cambridge University Law Press.

Dean M (1994) Critical and Effective Histories: Foucault's Methods and Historical Sociology. London: Routledge.

Death C (2013) Governmentality at the limits of the international: African politics and Foucauldian theory. Review of International Studies 39(3): 763-787.

Donnelly J (2013) Universal Human Rights in Theory and Practice. New York: Cornell University Press.

Elkin SL and Soltan KE (eds) (1993) A New Constitutionalism: Designing Political Institutions for a Good Society. Chicago, IL: The University of Chicago Press.

Evans T (2003) Universal human rights: ‘As much round and round as ever onward'. International Journal of Human Rights 7(4): 155-168.

Evans T (2005) International human rights law as power/knowledge. Human Rights Quarterly 27(3): 1046-1068.

Ewald F (1991) Norms, discipline, and the law. In: Post R (ed.) Law and the Order of Culture. Berkeley, CA: University of California Press, pp. 138-161.

Fine B (1984) Democracy and the Rule of Law: Liberal Ideals and Marxist Critiques. London: Pluto Press.

Foucault M (1972) Archaeology of Knowledge. London: Tavistock.

Foucault M (1977) Discipline and Punish: The Birth of the Prison. Harmondsworth: Penguin.

Foucault M (1980) Power/Knowledge: Selected Interviews and Other Writings, 1972-1977. New York: Pantheon.

Foucault M (1991) Governmentality. In: Burchell G, Gordon C and Miller P (eds) The Foucault Effect: Studies in Governmentality. London: Harvester Wheatsheaf, pp. 87-104.

Foucault M (1993) About the beginning of the hermeneutics of the self: Two lectures at Dartmouth. Political Theory 21(2): 198-227..

Foucault M (2000) The subject and power. In: Faubion JD (ed.) Essential Works of Foucault 19541984. Vol. 3: Power. New York: The New Press, pp. 326-348.

Foucault M (2007) Security, Territory, Population: Lectures at the Collège de France, 1977-78. New York: Palgrave Macmillan.

Franke MF (2011) The unbearable rightfulness of being human: Citizenship, displacement, and the right to not have rights. Citizenship Studies 15(1): 39-56.

Garland D (1997) 'Governmentality' and the problem of crime. Theoretical Criminology 1(2): $173-214$.

Garland D (2002) The Culture of Control: Crime and Social Order in Contemporary Society. Chicago, IL: The University of Chicago Press.

Golder B and Fitzpatrick P (2009) Foucault's Law. New York: Routledge.

Gordon C (1991) Governmental rationality: An introduction. In: Burchell G, Gordon C and Miller P (eds) The Foucault Effect: Studies in Governmentality. London: Harvester Wheatsheaf, pp. 1-51.

Guzik K (2013) Security a la Mexicana: On the particularities of security governance in México's War on Crime. Theory and Society 42(2): 161-187.

Hammer LM (2007) A Foucauldian Approach to International Law: Descriptive Thoughts for Normative Issues. Aldershot: Ashgate.

Hirschl R (2009) Towards Juristocracy: The Origins and Consequences of the New Constitutionalism. Cambridge, MA: Harvard University Press.

Hirst PQ (1986) Law, Socialism and Democracy. London: Allen \& Unwin.

Horne J (2006) Focus: crimes against international humanitarian law: International trials in perspective. European Review 14(4): 415-419. 
Hunt A and Wickham G (1994) Foucault and Law: Towards a Sociology of Law as Governance. London: Pluto Press.

Hutchings K (1997) Foucault and international relations theory. In: Lloyd M and Thacker A (eds) The Impact of Michel Foucault on the Social Sciences and Humanities. Houndmills: Palgrave Macmillan, pp. 102-127.

ICC Press Release (2013a) President of the Assembly visits The Hague and participates in the celebrations of the Day of International Criminal Justice. ICC-ASP-20130716-PR933, 16 July 2013. Available at: http://www.icc-cpi.int/en_menus/icc/press $\% 20$ and $\% 20$ media/press $\% 20$ releases/Pages/pr929.aspx (accessed 3 August 2015).

ICC Press Release (2013b) President Intelmann on approval of motion in the Parliament of Kenya to start the withdrawal process from the Rome Statute. ICC-ASP-20130906-PR938, 6 September 2013. Available at: http://www.icc-cpi.int/en_menus/icc/press\%20and\%20media/ press\%20releases/Pages/pr938.aspx (accessed 3 August 2015).

Joseph J (2010) The limits of governmentality: social theory and the international. European Journal of International Relations 16(2): 223-246.

Joseph J (2012) The Social in the Global: Social Theory, Governmentality and Global Politics. Cambridge: Cambridge University Press.

Kiersey NJ and Stokes D (eds) (2013) Foucault \& International Relations: New Critical Engagements. New York: Routledge.

Koskenniemi M (2002) The Gentle Civilizer of Nations. Cambridge: Cambridge University Press.

Krahmann E (2003) Conceptualizing security governance. Cooperation and Conflict 38(1): 5-26.

Krasmann S (2012) Law's knowledge: On the susceptibility and resistance of legal practices to security matters. Theoretical Criminology 16(4): 379-394.

Larner W and Walters W (eds) (2004) Global Governmentality: Governing International Spaces. London: Routledge.

Lea J and Stenson K (2007) Security, sovereignty, and non-state governance 'from below'. Canadian Journal of Law and Society 22(2): 9-27.

Legg S (2012) 'The life of individuals as well as of nations': International law and the League of Nations' anti-trafficking governmentalities. Leiden Journal of International Law 25(03): 647-664.

Lemke T (2002) Foucault, governmentality, and critique. Rethinking Marxism 14(3): 49-64.

Manokha I (2009) Foucault's concept of power and the global discourse of human rights. Global Society 23(4): 429-452.

Martin M and Owen T (2013) Routledge Handbook of Human Security. New York: Routledge.

Merry SE (2001) Spatial governmentality and the new urban social order: Controlling gender violence through law. American Anthropologist 103(1): 16-29.

Miller P and Rose N (2008) Governing the Present: Administering Economic, Social and Personal Life. Cambridge: Polity Press.

Munro VE (2001) Legal feminism and Foucault - a critique of the expulsion of law. Journal of Law and Society 28(4): 546-567.

Mythen G and Walklate S (2006) Criminology and terrorism which thesis? Risk society or governmentality? British Journal of Criminology 46(3): 379-398.

Nah AM (2012) Globalisation, sovereignty and immigration control: The hierarchy of rights for migrant workers in Malaysia. Asian Journal of Social Science 40(4): 486-508.

Neumann IB and Sending OJ (2010) Governing the Global Polity: Practice, Mentality, Rationality. Ann Arbor: University of Michigan Press.

New Vision - Uganda's Daily Leading (2014a) Museveni blasts ICC over Kenyatta trial, 9 October. Available at: http://www.newvision.co.ug/news/660584-museveni-blasts-icc-overkenyatta-trial.html 
New Vision - Uganda's Daily Leading (2014b) I will go to ICC - Uhuru, 6 October. Available at: http://www.newvision.co.ug/news/660455-i-will-go-to-icc-uhuru.html

Nouwen SM and Werner WG (2010) Doing justice to the political: The International Criminal Court in Uganda and Sudan. European Journal of International Law 21(4): 941-965.

Orford A (2012) In praise of description. Leiden Journal of International Law 25(3): 609-625.

Pavlich G (2001) Introduction: Transforming images, society, law and critique. In: Wickham G and Pavlich G (eds) Rethinking Law, Society and Governance: Foucault's Bequest. Oxford: Hart, pp. 1-9.

Rabinow P (1984) The Foucault Reader. New York: Pantheon.

Rajkovic NM (2012) 'Global law' and governmentality: Reconceptualizing the 'rule of law' as rule 'through' law. European Journal of International Relations 18(1): 29-52.

Raphael DD (1966) The liberal western tradition of human rights. International Social Sciences Journal 18(1): 22-30.

UN Security Council (2005) Report of the International Commission of Inquiry on Darfur to the Secretary-General. S/2005/60, 1 February 2015. Available at: http://www.securitycouncilreport.org/atf/cf/\%7B65BFCF9B-6D27-4E9C-8CD3-CF6E4FF96FF9\%7D/WPS\%20S\%20 2005\%2060.pdf (accessed 3 August 2015).

Rose N and Valverde M (1998) Governed by law? Social and Legal Studies 7(4): 541-551.

Rosenau JN and Czempiel E-O (eds) (1992) Governance without Government: Order and Change in World Politics. Cambridge: Cambridge University Press.

Rosenow D (2009) Decentring global power: The merits of a Foucauldian approach to international relations. Global Society 23(4): 497-517.

Schabas WA (2011) An Introduction to the International Criminal Court. Cambridge: Cambridge University Press.

Scheffer DJ (2002) Staying the course with the International Criminal Court. Cornell International Law Journal 35(1): 47-100.

Schiff BN (2008) Building the International Criminal Court. Cambridge: Cambridge University Press.

Schneiderman D (2015) Constitutional property rights and elision of the transnational: Foucauldian misgivings. Social and Legal Studies 24(1): 65-87.

Schwöbel C (ed.) (2014) Critical Approaches to International Criminal Law: An Introduction. New York: Routledge.

Selby J (2007) Engaging Foucault: Discourse, liberal governance and the limits of Foucauldian IR. International Relations 21(3): 324-345.

Slaughter AM (2009) A New World Order. Princeton, NJ: Princeton University Press.

Song SH (2013) Annual report to the United Nations General Assembly, 31 October 2013. Available at: http://www.icc-cpi.int/iccdocs/presidency/Pres-statement-31-10-2013-Eng.pdf (accessed 3 August 2015).

Stahn C and Sluiter G (2009) The Emerging Practice of the International Criminal Court. Leiden: Martinus Nijhoff.

Stenson K (2005) Sovereignty, biopolitics and the local government of crime in Britain. Theoretical Criminology 9(3): 265-287.

Stone Sweet A (2006) The new Lex Mercatoria and transnational governance. Journal of European Public Policy 13(5): 627-646.

Struett MJ (2008) The Politics of Constructing the International Criminal Court: NGOs, Discourse, and Agency. New York: Palgrave Macmillan.

Sudan Tribune (2010) African Union moves aggressively to shield Bashir from prosecution, 29 July 2010. Available at: http://www.sudantribune.com/spip.php?article35786 (accessed 3 August 2015).

Tadros V (1998) Between governance and discipline: The law and Michel Foucault. Oxford Journal of Legal Studies 18(1): 75-103. 
UNDP (1994) Human Development Report. New York: Oxford University Press.

UNGA A/68/314 (2013) UN General Assembly. Report of the International Criminal Court, 13 August 2013, paras 98-105. Available at: http://www.icc-cpi.int/en_menus/icc/reports\%20 on\%20activities/court\%20reports\%20and\%20statements/Documents/9th-report/N1342653. pdf (accessed 3 August 2015).

Veyne P (1997) Foucault revolutionizes history. In: Davidson Arnold I (ed.) Foucault and His Interlocutors. Chicago, IL: The University of Chicago Press, pp. 146-182.

Vincent RJ (1986) Human Rights and International Relations. Cambridge: Cambridge University Press.

Walby K (2007) Contributions to a post-sovereigntist understanding of law: Foucault, law as governance, and legal pluralism. Social and Legal Studies 16(4): 551-571.

Walters W (2012) Governmentality: Critical Encounters. London: Routledge.

Wickham G (2006) Foucault, law, and power: a reassessment. Journal of Law and Society 33(4): 596-614.

\section{Author biography}

Gozde Turan has a PhD in International Relations from Bilkent University. Her research interests include international criminal law, criminal tribunals and critical theory. 